\title{
Moving Targets? Texts, language, archaeology and history in the Late Vedic and early Buddhist periods
}

\section{Citation}

Witzel, Michael E. J. 2009. Moving Targets? Texts, language, archaeology and history in the Late Vedic and early Buddhist periods. Indo-Iranian Journal 52(2-3): 287-310.

\section{Published Version}

doi:10.1163/001972409X12562030836859

\section{Permanent link}

http://nrs.harvard.edu/urn-3:HUL.InstRepos:8457940

\section{Terms of Use}

This article was downloaded from Harvard University's DASH repository, and is made available under the terms and conditions applicable to Open Access Policy Articles, as set forth at http:// nrs.harvard.edu/urn-3:HUL.InstRepos:dash.current.terms-of-use\#OAP

\section{Share Your Story}

The Harvard community has made this article openly available.

Please share how this access benefits you. Submit a story.

Accessibility 
Michael Witzel

Moving Targets? Texts, language, archaeology and history in the Late Vedic and early Buddhist periods

\section{ABSTRACT}

The Late Vedic and earliest Buddhist texts are investigated to indicate their relative historical layering. Besides the texts themselves, their language, place names, archaeological and their inherent historical background are brought to bear. These data and those on some historical contemporaries of the Buddha do not indicate a correlation with late Vedic personalities and texts. A certain period of time separates both corpora.

\section{KEYWORDS}

Veda, Upanisad, Buddha, Pāli, Buddhist canon, Kosala, Videha, Magadha, Vajji, Pasenadi, Bimbisāra, Ajātasattu, urbanization, ascetics, Herodotus, Pānini, chandas.

\section{\$ 1. The problem}

The literary and political history of India during the lifetime of the Buddha has remained enigmatic. How much actual historical information do we possess? Do early (prePăli) Buddhist texts follow on Late Vedic texts, as common opinion has it, or do they overlap with it, if only to some extent? ${ }^{1}$ What do these texts tell us about actual history of the period, "wie es wirklich gewesen" (Ranke)? And, what are their respective absolute dates?

However, some of these questions may have been put the wrong way. As we will see, we rather are dealing here with two moving targets. Both text corpora have still not been explored sufficiently well as to establish either the beginning of actual Buddhist text formation, or the end of Vedic text formation and the closure of the Vedic corpus. ${ }^{2}$

\footnotetext{
1 Cf. J. Bronkhorst, Greater Magadha Studies in the Culture of Early India. Leiden: Brill 2007.

2 M. Witzel, The Development of the Vedic Canon and its Schools: The Social and Political Milieu. In: Inside the Texts, Beyond the Texts. New Approaches to the Study of the Vedas. Harvard Oriental Series. Opera Minora, vol. 2. Cambridge 1997, 257-345; cf. L. L. Patton, Authority, Anxiety and Canon. Essays in Vedic interpretation. Albany, SUNI Press 1994; Bronkhorst, Greater Magadha, 2007.
} 
This has recently emphasized by oskar von Hinüber: "... early Buddhist historiography ... is deplorably absent..." and later on, "our sources never allow us to go beyond more or less likely or probable conclusions about the roots of the texts that reach far back into period of early Buddhism", adding the same caveat for the date of the closure of a text. ${ }^{3}$

As a further caveat, it must be underlined that I leave aside, for the most part, the development of thought, philosphy and religion. It remains a difficult undertaking to trace their multiple strands, impossible to carry out in a brief paper." Rather, I will concentrate on some aspects of archaeology, material culture, language, society and contemporary history.

\section{\$2 Materials}

In order to establish what occurred in the various parts of North India, and during which periods, both the locations of the individual texts and their relative or, better, their absolute dates need to be ascertained. Only on this basis it will be possible to illuminate what each text or group of texts from the various geographical regions and the various time levels involved can tell. However, in spite of some recent advances, much work still needs to be done in this respect.

The location of most Vedic texts of this period has been established fairly well over the past few decades. ${ }^{5}$ However, it is still difficult to pinpoint the geographical location individual Pāli texts, even if one can be generally sure that the earliest texts of the canon were composed in the eastern part of Northern India, mainly in the Kosala (Audh), Kāśi, Bihar and Magadha areas. ${ }^{6}$

3 o. v. Hinüber, Hoary past and hazy memory, JIABS 9, 2008, p. 209. 4 For this, see J. Bronkhorst, Greater Magadha, Leiden: Brill 2007, cf. nevertheless the question of asceticism, below.

5 M. Witzel, on the localisation of Vedic texts and schools. In: G. Pollet (ed.), India and the Ancient world. History, Trade and Culture before A.D. 650. P.H.L. Eggermont Jubilee Volume, Orientalia Lovaniensia Analecta 25, Leuven 1987, pp. 173-213; cf. K. Mylius, Geographische Untersuchungen zur Entstehungsgegend des ŚtapathaBrāhmana, Wiss. Zeitschr. der Karl-Marx-Universität Leipzig 14, 1965, 759-761.

6 However, the introduction phrase to individual texts ("at this time the Lord stayed at...") often is doubtful. See oskar von Hinüber, Hoary Past, JIABS 9, 2008, and G. Schopen, If You Can't Remember, How to Make It Up: Some Monastic Rules for Redacting Canonical Texts, in: Buddhist Monks and Business Matter. Still More Papers on Monastic Buddhism in India. Honolulu 2004, 395-407 
The relative timeframe of the Vedic texts, however, is well established: they are layered in five levels ${ }^{7}$ from the Rgveda down to the oldest Upanisads (Brhadaranyaka Upani.sad, Jaiminīya Upani.sad Brāhmạna, Chāndogya Upani.sad). Yet, there still is no reliable absolute dating for these texts.

However, the language and content of Late Vedic texts, seen in the earliest Upanișads, overlap with those of late Brāhmana texts, such as the first section of the (JB 1.1-1.65) or the independent appendix to the Taittirīya texts, the Vādhūla Anvākhyāna. They point to a living Vedic language at a time when the Buddha (like later on, Pạnnini) still could call Vedic Sanskrit "chandas" ('metrical').8 This is the period of the Late Vedic 'southeastern Koine. '9 Both language and shared stories (both little researched) ${ }^{10}$ point to the same period. The area is congruent with the Kosala, Kăsí, Vajji and Magadha territories of the early Buddhist texts.

There also are some small sections in the Late Vedic texts Upanisads that can be suspected to be post-Buddha, ${ }^{11}$ and the final form of Vedic texts seems to have undergone some minor phonetic shifting and adjustment ${ }^{12}$ until about the time of Pānini (c. 350 BCE) as they reflect some of his euphonic rules. ${ }^{13}$

7 M. Witzel, Tracing the Vedic dialects, Tracing the Vedic dialects. In: Colette Caillat (ed.), Dialectes dans les littératures indo-aryennes. Paris : Collège de France/Institut de Civilisation Indienne, 1989, 97-264, esp. p.121-128

${ }^{8}$ Perhaps the Eastern Vedic, with the two tone bhasisika accent of the Ś is intended, see below.

9 Meaning the Late Vedic language of the East and of the JB, south of the Ganga and Yamuna). See $M$. Witzel, On the origin of the literary device of the 'Frame Story'. In: H. Falk (ed.) Old Indian

literature. Hinduismus und Buddhismus, Festschrift für U. Schneider, Freiburg 1987, 380-414.

${ }^{10}$ See N. Tsuji, Genzon Yajuruvēda Bunken, Tokyo: Tokyo Bunko 1970, 32sq9, 75; M. Witzel, on the origin of the literary device of the 'Frame Story', 1987; M. Witzel, The case of the shattered head. Festschrift für W. Rau, (= StII 13/14), Reinbek 1987, 363-415.

11 Bronkhorst, Greater Magadha 2007, M. Witzel, Yājavalkya as ritualist and philosopher, and his personal language. In: Adhami, S. (ed.) Paitimana. Essays in Iranian, Indo-European, and Indian Studies in Honor of Hanns-Peter Schmidt. Volumes I \& II. Casta Mesa CA: Mazda Publishers 2003, 103-143.

${ }^{12}$ This refers only to some aspects of the redaction (as different from composition) that took place until and even after pānini, or rather his type of Sanskrit. This is visible, for example, in the treatment of the Abhinihita Sandhi with restored a- in most of $R V$ and later Vedic texts, cf. J. Bronkhorst, Greater Magadha, on these problems. In addition there remains the problem of an early written ŚB (Kānva) text, see Witzel, Tracing the Vedic dialects, p. 240, n.334, and: Variant Readings in the Rgveda? Presentation at the 14th World Sanskrit Conference, Kyoto 2009. http://WwW.indology.bun.kyotou.ac.jp/14thWSC/programme/01/Witzel.pdf paper at the 14th World Sanskrit Conference, Kyoto, 2009. 13 This has to be kept separate from J. Bronkhorst's assertion, (Greater Magadha, 2007) that Vedic text were still actively composed after the Buddha. See below for counter-evidence. 
However, it is much more difficult to determine the absolute time of individual texts and of groups of texts as such. The late Vedic texts commonly are dated as following centuries of Middle and Early Vedic texts (after and before c. $1000 \mathrm{BCE}$ respectively), ${ }^{14}$ while the late Vedic ones are usually dated, in absolute time, as being preBuddha, thus before C. 400 BCE.

The situation is still not that clear for the earliest texts of Buddhism. It is well known that we do not have the original sermons of the Buddha composed in an early eastern Middle Indo-Aryan dialect, but that we just have their transpositions into a western MIA literary language, Pāli, as well as later adaptations into other languages. ${ }^{15}$

To establish which were the earliest Buddhist texts and their layering still is a work in progress. However, the Pătimokkha formulas, to be recited monthly, or a large section of the suttanipata belong to this level. ${ }^{16}$ It is also well known that the Pāli texts have undergone collection and canonization at the council of Pătaliputra during the reign of the emperor Aśoka.

The actual layers within the Păli canon are even less clear. Apparently, we have to reckon with pre-Aśokan texts (before C. 250 BCE), Aśokan texts (c. 250 BCE) and postAśokan texts. But which particular text of the multitude of Păli texts (or which stratum of a text) belonged to which period still is largely unresolved. ${ }^{17}$

In short, we must deal here with two moving targets: on the one hand, the temporal extent of the late vedic texts as well as their canonization and final redaction (that may taken place considerably later), and on the other, a similar problem for the pali canon, its beginnings, layering and redaction.

In this situation, it is useful to take a closer look at the overlap, if any, of factual data that can be found in both corpora. Some are obvious, such as the use of some rare words that do not occur, or do not widely occur, before both kinds of texts and that are sometimes

14 Cf. now M. Witzel, Das Alte Indien. München: Beck 2003: 25.

15 o. v. Hinüber, Das ältere Mittelindisch im Überblick. 2., erweiterte Auflage, Wien: Verlag der Österreichischen Akademie der Wissenschaften 2001.

16 o. v. Hinüber, Das ältere Mittelindisch, \$ 34, p. 63, Hideaki Nakatani, Buddha no Konron. In: Koten no Sekaizō, Kobe: Heisei 15 [2003] 32-50.

17 Though see several individual works on this topic, especially by 0. v. Hinüber, listed his Das ältere Mittelindisch, in his $A$ Handbook of Pāli Literature. Berlin: de Gruyter 1996; see also his «Hoary Past», JIABS 9, 2008, 204, on his linguistic notes on the Mahāparinibbānasuttanta of the Vinaya, at C. 350-320 BCE. 
restricted to eastern North Indial ${ }^{18}--$ a voluminous task that cannot be undertaken here. However, the combination of textual, archaeological, cultural and political data from both classes of texts results, to begin with, in the following table.

TABLE 1.

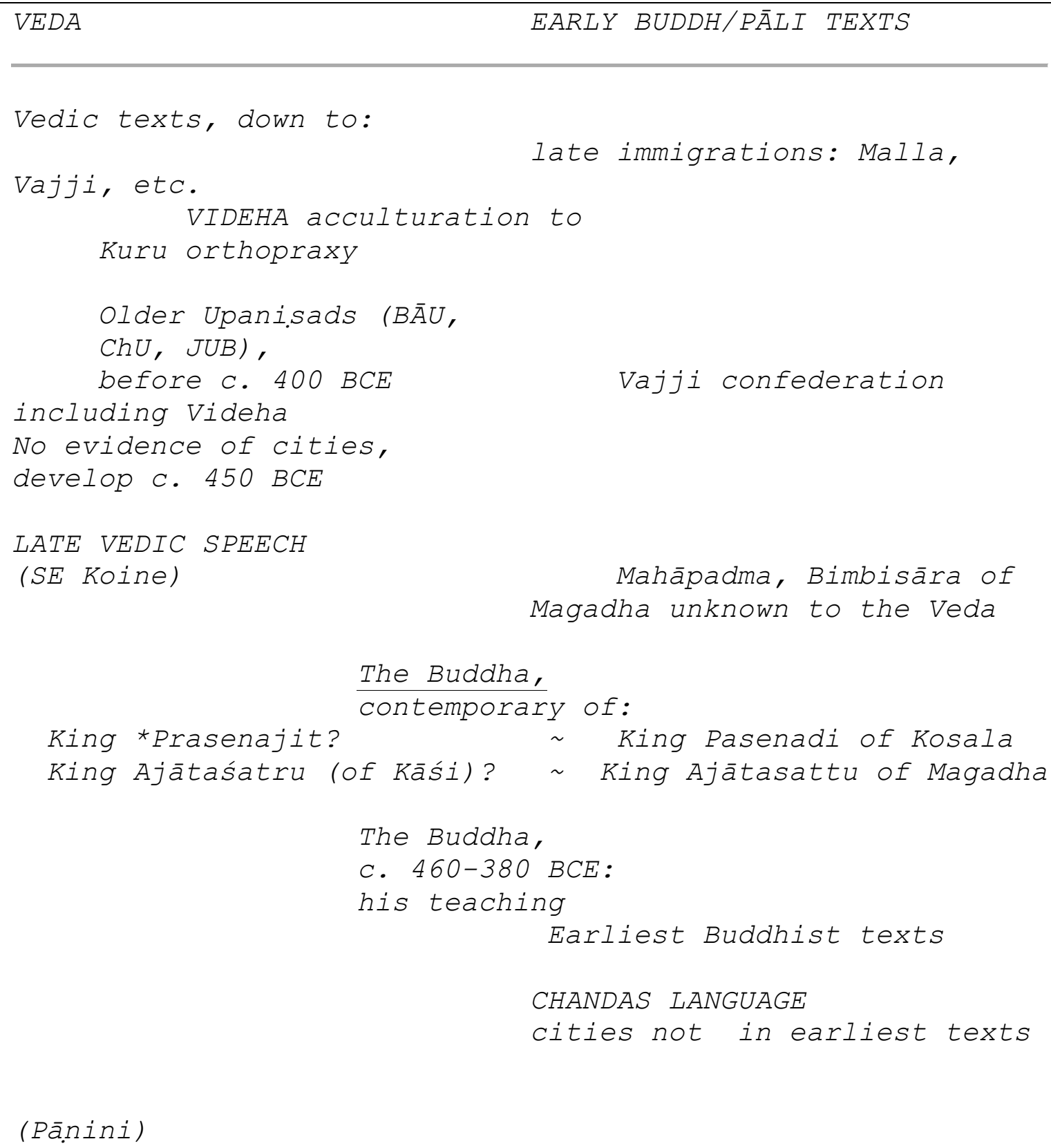

18 Such as viśäla, pāpa (M. Witzel, Tracing the Vedic dialects, $p$. 205, n.266; Hideaki Nakatani, Buddha no Konron p. 40), punar mr, karma, and certain substrate words $10 . \mathrm{V}$. Hinüber, Das ältere Mittelindisch \$ 72), including the snake name Mucilinda; further: argala/argadalirgala, argaliká'bolt' (Turner, CDIAL 629, cf. additions to this by $F$. Southworth in the SARVA substrate dictionary (in progress), entry S629, see: http://www.aa.tufs.ac.jp/sarva/entrance.html. 


\begin{tabular}{|lcc|}
\hline Collection/redaction, $C .350$ & $B C E ?$ & transposition into \\
\hline Păli & \\
\hline $250 \mathrm{BCE}$ & Collection/redaction, $C$. \\
\hline
\end{tabular}

\section{\$2. Language}

It is well known that the Buddha's sermons and speeches were given in an early eastern ${ }^{19}$ Middle Indian dialect of Kosala-Videha, probably approaching that of the "middle country", Majjhimadesa, ${ }^{20}$ a small area in Malla country close to his home in Lumbini and Kapilavastu, with early texts in a "Buddhist Middle Indian» Iingua franca. ${ }^{21}$

It is also clear that later on a transposition of these texts in a «Buddhist Middle Indic» has taken place into the western 'literary' language, Păli, ${ }^{22}$ and that these texts were then collected and redacted at the so-called Third Council under the great King Aśoka, at Pătaliputra, C. $250 \mathrm{BCE}$. Some additional texts were included at least until, and sometimes beyond, the supposedly first written version emerged in Sri Lanka, shortly before the beginning of the common era ${ }^{23}$ and more than a century before the extant manuscripts in another MIA language, Gāndhārī. ${ }^{24}$ Some residues of the eastern dialect are still visible in our current Pāli texts, a problem that $0 . v$. Hinüber has contributed to substantially. ${ }^{25}$

However, the layering of the extant Pāli texts is not as well established as that of the Vedic canon. Again, 0. v. Hinüber has made important contributions to this problem, but the large extent of the materials -many of them having multiple internal layering - does not yet allow

\footnotetext{
19 See O. v. Hinüber, Das ältere Mittelindisch, \$ 36 p. 64, \$ 38 p. 65 with lit.; cf. K.R. Norman, The dialects in which the Buddha Preached. In: H. Bechert (ed.) Die Sprache der ältesten buddhistischen Überlieferung. Göttingen 1980, 61-77 = Collected Papers II, 128-147.

20 At Vin. I 197,27 defined by a brāhmanagāma in Malla land, Thūna; later on, the area is expanded, see G.P. Malalasekara, Dictionary of Päli proper names. London: Pali Text Society 1974 [1937], Vol. II $418 \mathrm{f}$. - Nowadays, Mades is the name of the plains of Southern Nepal. 21 See O. v. Hinüber, Das ältere Mittelindisch, \$ 39, p. 40.

22 See $0 . v$. Hinüber, Das ältere Mittelindisch, $\$ 3$ p. 36, \$ 48-40 p. 64 ff., $\$ 39, p .66$.

23 Allegedly, nder Va.t.tagāmañ Ả Ahaya 87-77 BCE.

24 See O. V. Hinüber, Das ältere Mittelindisch, \$ 33, p. 62.

25 See for example his work on the perfect tense, Das ältere Mittelindisch, \$ 480, p. 304 sq.; cf. the earlier, ground-breaking work on the Urkanon by $H$. Lüders, summarized by H. Bechert, Die sprache der ältesten buddhistischen Überlieferung, p. 11-16.
} 
for a comprehensive picture and summary, -- though we have such important studies as that of the Suttanipata. ${ }^{26}$

In general we can rely on the first canonization of the Pāli texts in Aśoka's time around 250 BCE. We must therefore extrapolate backwards to the life time of the Buddha, c. 460-380 BCE, in order to reach the earliest form of his sermons and speeches. This will also remain a problem in this paper throughout. I will thus clearly distinguish between «earliest Buddhist texts» of the Buddha's life time and those of the Pāli canon some 150 years later. 27

One way to get a closer handle on the problem is to investigate the language of both corpora closely, as language usually is a good yard stick for the age of a text, -- that is, unless an author intentionally used archaic forms. ${ }^{28}$ Unfortunately, this kind of evidence is again clear in the Veda, but less so in Pāli texts, as these have constantly been updated and, in part, even Sanskritized. ${ }^{29}$

One has occasionally tried to achieve a historical layering of Pāli texts. ${ }^{30}$ We therefore have to rely on archaic or more modern forms in individual texts, such as the Patimokkha formula or the oldest sections of the Suttanipàta. Again: we have to deal with a moving target. However, we can compare such forms with the archaeologically attested ones in Asoka's inscriptions and compare these data with those in Late Vedic texts, even if both forms of Indo-Aryan are from different forms of speech and social registers.

First of all, there is awareness of late Vedic speech (as well as of many aspects of Brahmanical life and rituals), ${ }^{31}$ in the canon, though this would still have to be specified as per - supposed-- text layer in the early

\footnotetext{
26 Hideaki Nakatani, Buddha no Konron.

27 Note L. Schmitthausen, An attempt to estimate the distance in time between Aśoka and the Buddha in terms of doctrinal history. In: H.Bechert (ed.) The dating of the historical Buddha.2. Göttingen: 1992, 110-147, 0. v. Hinüber, A Handbook of Päli Literature, \$ 98. 28 Note, even then, the many later Upanisads with beginnings imitating Vedic sentences

${ }^{29}$ See for example 0 . V. Hinüber's discussion of the absolutives in tvā, Das ältere Mittelindisch \$ 498 p. 314 etc., for Sakya see Nakatani, Buddha no konron p. 39; with some changes down to the the 19th century Council in Burma.

30 See for example, Paul Kingsbury, The Chronology of the Pali canon. The case of the Aorist. PhD Diss., Univ. of Pennsylvania.

Philadelphia 2002. Cf. his summary paper Inducing a chronology of the Pali canon, http://www.ling.upenn.edu/ kingsbur/inducing.pdf. This approach however, does not succeed as the author has adjusted his texts to a predestined mathematical curve.

31 See Bronkhorst, Greater Magadha 2007; H. Falk, Vedische Opfer im Pali-Kanon. Bulletin des Etudes indiennes 6, 1988, 225-254.
} 
Buddhist texts, ${ }^{32}$ again a task that cannot be undertaken here.

Nevertheless, the Buddha is well aware of Late Vedic speech, which he calls chandas, just as Pānini does, maybe about half a century later. The designation is unusual in the Vedic texts that distinguish between Mantra, Brāhmana and, occasionaly, Kalpa (Sütra). But it can be understood when comparing the (educated) spoken language, bhàsā, that Pănini mainly teaches, along with the (older) hieratic Vedic whose Mantras are largely composed in metrical fashion, employing chandas (meter). The distinction for both will thus rather have been one between local levels of speech (OIA, MIA) and the hieratic one of Vedic Mantras and prose composed in the same "style».

Furthermore, Vedic (and even Pānini's bhăsa) still had tonal (pitch) accent, which additionally will have distinguished it from the MIA of the Buddha's time. ${ }^{33}$

However, an additional point may be that Eastern OIA, and even the eastern Vedic of the Śatapatha Brāhmana, had a two tone accent system (the confusingly so-called bhäsiska accents, see Bhāsika Sūtra); ${ }^{34}$ while western (Kuru-Pañcāla) Vedic and the Gandhāra bhăsā had a three tone accent system of Anudātta, Udātta and Svarita. The latter was introduced into the East for liturgical purposes, as seen in the Samhitā beloging to the Śatapatha Brāhmana, where it clashes with the bhäsika accents, ${ }^{35}$ and with which clash the Mimāmsakas, such as Śabara, still had to struggle, many centuries later.

It is thus imaginable that the Buddha's admonition to propagate his teachings not in chandas language ${ }^{36}$ may refer either to the highly hieratical Vedic of the Samhitas or rather to the high level speech of Vedic prose (Brāhmana, early Upanisads, BŚS of Kosala) used by contemporary Brahmins in teaching contexts.

Apart from this, there are numerous features in late Vedic and the MIA of the early Buddhist texts that overlap across language boundaries, as both forms of Indo-Aryan were used by people that were actually interacting with

\footnotetext{
32 See for example the detailed 3-tier layering in H. Nakatani, Buddha no Konron.

33 Pitch accent no longer existed in MIA; however, the oldest

Buddhist texts were composed when Vedic pitch accent still was spoken, see O. V. Hinüber, Das ältere Mittelindisch \$ 159: p. 145, $\$ 247, \$ 283$.

34 M. Witzel, Tracing the Vedic dialects, p. $226 \mathrm{n} .317$; cf. n. 334 , n. 226, 230, 355; for a scholastic, pandit-like approach to the problem, see G. Cardona, The Bhäsika Accentuation System. Studien zur Indologie und Iranistik 18, 1993, 1-40.

35 M. Witzel, Tracing the Vedic dialects, $n$. 317, and: The Development of the Vedic Canon and its Schools.

36 K. R. Norman, chandasi aropetam. In: H. Bechert (ed.) Die Sprache der ältesten buddhistischen Überlieferung. Göttingen 1980.
} 
each other on a daily basis. For example, there are unusual late, colloquial features in Chāndogya Upani.sad 6. ${ }^{37}$

other items such as the use of the perfect in narrative contexts stand out. In Late Vedic texts of the Center and East of northern India, the perfect replaced the earlier use of the imperfect. ${ }^{38}$ This is standard in texts such as the $S B$ and $B \bar{A} U$. However, the JB, largely composed and collected in the western lands south of the rivers Yamunā and Gañgā, had a mixed use of imperfect (for traditional, mythological tales) and perfect (for reports of more recent occurences) in natural speech, with a strong showing of the Aorist, especially when reporting facts with results in the present (the former domain of the perfect). 39

The latter situation can be seen as the predecessor to the complete domination of the aorist in reporting the past in Păli, which is, after all, like the JB's, a western MIA language. The contrast between the few (5) remnants of the perfect in Pāilio that go back to eastern MIA usage of the Buddha's area of activity and the western Pāli cannot be starker. ${ }^{41}$ Both stages of early MIA clearly overlap with the developments in Late Vedic, ${ }^{42}$ even if Pāil is younger by several hundreds of years.

There also are several other nominal and verb forms as well as interjections ${ }^{43}$ and finally, some individual words that are of interest in this context. Remakable is the increase in the usage of papa 'evil' in the late Vedic texts $^{44}$ and the earliest layer of the Suttanipāta, ${ }^{45}$ surely an indication of the increasing ethicization of the karma concept in Late Vedic leading to the origin of the

\footnotetext{
37 See K. Hoffmann, Aufsätze zur Indoiranistik, ed. J. Narten, Wiesbaden 1976: 370 sqq., on ChU 6 (with Uddālaka Āruni) as «the youngest level of Vedic prose; cf. also on the Ksatriya dialect in the somewhat later Middle Upanisads: R. Salomon, Linguistic analysis of the Mundaka Upanisad, WZKS 25, 1981, 91-105.

38 M. Witzel, Tracing the Vedic dialects, p. 139 sqq.

39 M. Witzel, on the origin of the literary device of the 'Frame Story'.

40 For the few remnants of the perfect see $0 . V$. Hinüber, Das ältere Mittelindisch, $\$ 480, p .34$ sq.

41 However, see now Eystein Dahl, Evidentiality in Late Vedic? Presentation at the $14^{\text {th }}$ World Sanskrit Conference, Kyoto 2009. http://WWw. indology. bun. kyoto-u.ac.jp/14thWSC/programme/02/Dahl.pdf. 42 Discussion in M. Witzel, Tracing the Vedic dialects, p. 208 sqq.

43 M. Witzel, Tracing the Vedic dialects; cf. O. V. Hinüber, Das älere Mittelindisch, $\$ 497:$. 312 sql.; C. Caillat, appendix to Witzel, Tracing the Vedic dialects, and in: Inside the Texts, Beyond the Texts. New Approaches to the Study of the Vedas. Harvard Oriental Series. Opera Minora, vol. 2. Cambridge 1997, 14-27; see the literature quoted in: O. V. Hinüber, Das ältere Mittelindisch, \$ 9, p. $41 \mathrm{sq}$.

44 M. Witzel, Tracing the Vedic dialects, p. 205 sqq..

${ }^{45}$ H. Nakatani, Buddha no Konron.
} 
karma/rebirth complex in the Upanisads, Buddhism and Jainism.

Clearly, even the earliest eastern MIA (the dialect still using perfects), Pāli and Aśokan MIA are several consecutive steps later than Late Vedic -- even when taking into account the different social register of speech. In sum, there is a clear time gap and only some marginal overlap between late Vedic and earliest MIA.

\section{\$ 3. Archaeological, social and political data.}

How should we proceed then, to evaluate the initial question? There is a number of data points in archaeology, historical place names, and near-contemporary authors that could be brought to bear.

\section{Archaeology and texts}

The late Vedic texts are not yet aware of cities ${ }^{46}$ before the so-called second urbanization of India of C. $450 \mathrm{BCE}$. The word nagara occurs only in very Late Brāhmana and Arranyaka texts, such as in the post-Pāninean part of Gopatha Br. (1.1.23), and in the Puranic-time part of Taittirīya Āranyaka (1.11.7, 1.31.2). ${ }^{47}$ Nagarin 'one who has/is characterized by a nagara' occurs only in a name, and always as the same person, Nagarin Jānaśruteya. He appears in Jaiminìya and Aitareya Brāhmana as well as in Jaiminìya Upani.sad Brāhmana, ${ }^{48}$ as belonging to the Dālbhya clan, once along with with Äruni, ${ }^{49}$

The absence of cities is also typical for the earliest level of Buddhist texts: the Buddha stayed and taught in villages, not cities. ${ }^{50}$

Notable are the place names in early Buddhist texts such as Rāja-gaha ('king's house'), or Pātali-gāma, the modern Patna. ${ }^{51}$ Only in later levels of the Päli texts do we find centrally located cities that are so typical for the

\footnotetext{
46 W. Rau. The Meaning of pur in Vedic Literature, [Abhandlungen der Marburger Gelehrten Gesellschaft III/1] München : W. Finck 1976; cf. K. Mylius, Gab es Städte im jungvedischen Indien? EthnographischArchäologische Zeitschrift 10, 1989, 33-39.

47 On TÄ 1 see: M. Witzel, An unknown Upani.sad of the Kr.s.na Yajurveda: The Ka.tha-Śik.sā-Upani.sad. Journal of the Nepal Research Centre, Vol. 1, Wiesbaden-Kathmandu 1977, 135 sqq; Die Ka.tha-Śik.sāUpani.sad und ihr Verhältnis zur Śik.sāvallī der Taittirīya-Upani.sad. WZKS Vol. XXIII, 1979, 5-28; WZKS XXIV, 1980, 21-82.

$48 \mathrm{JB}$ 1. 11, etc. 1.247, 2.397, 2.409, $2.423=\mathrm{JB} \$ 4,90,161,167$, 168; JUB 3.40.2, $A B$ 5.30.

49 JB 2.397; see below on Brahmadatta.

50 O. v. Hinüber, Hoary Past, JIABS 9, 2008: 197 sqq.

51 0. v. Hinüber Hoary Past, JIABS 9, 2008: 202, on Pāttali-gāma becoming Pă.tali-putta, not yet a capital.
} 
texts, i.e. Campā, Rājagaha, Sāvatthi, Sāketa (Ayodhyā), Kosāmbi, Bārānasi, (Dịghanikāya II 169,11).

This agrees with the two levels of archaeologically attested settlements of the East: Kosala, Videha, Magadha are not characterized by the expanding western, Kurudominated Painted Grey Ware (PGW) culture of Haryana and Uttar Pradesh. It had a three-tiered settlement structure of villages, market places, and towns and extended up to the lower Doāb area of Vamśa/Kausāmbi, just west of the Allahabad. Instead, the East was characterized by the indigenous Black and Red Ware/Ochre Colored Pottery (BRW/OCP) culture that had only two-tiered settlements (villages and market places) during the pre-450 BCE period.

The Buddha is said to have given his speeches and sermons in the Kāśi, Magadha, Malla, Sakya, Vajji (Vrji), and even in the Kuru area. (Notably Videha, the new home of Brahmanical orthopraxy, is missing). In that context, the earliest Buddhist texts speak only of villages (gāma) and market places (nigama) as his locations, clearly reflecting the two-level settlements of OCP/BRW archaeology. Many if them are unknown little villages in Kosala, Magadha, or Kuru.

The Buddha thus spent much of his life (c. 460-380 $B C E)$ in a pre-urban society of villages and market places: in many cases he visited villages, and cities (nagara) only in his later life, such as those of the kings Pasenadi, Bimbisāra and Ajātasattu.

They include Campā (in Anga), Rājagaha (in Magadha), Sāvatthi and Sāketa (in Kosala), Kosāmbi (in Vamśa, in the lower Doāb), and Bārānasi (Kāśi), ${ }^{52}$ but not yet Pāttaliputta (Patna). These cities are usually mentioned in the introduction to a sermon, most frequently Sāvatthi: "at one time, the Lord stayed at... ${ }^{53}$ and many of them have been added to the canon only later on, sometimes with contradictions involved, and later on even artificially. ${ }^{54}$

The Buddha thus seems to have lived in the period of the second urbanization of India that saw the sudden emergence, rapid rise and expansion of cities, long distance trade, etc. In this respect, Late Vedic and early Buddhist texts overlaps for the earlier part of the Buddha's life.

\section{Place names}

This scenario agrees with the actual names found in the Pāli canon (before urbanization): only gāma (Skt. grāma)

\footnotetext{
52 As per Dīghanikāya 2.169.11.

53 O.v. Hinüber, Hoary Past, JIABS 9, 2008: 198.

54 G. Schopen: If You Can't Remember. If one was in doubt, one should insert Śrāvasthī.
} 
'village' and nigama 'market place' but not yet nagara 'city' are found. $O$. $v$. Hinüber has recently indicated a number of (Brahmin) villages that remain totally unknown, except for their mentioning in the canon. ${ }^{55}$

In such cases, the Vedic and older pāli texts use "Ortnamenparenthese," that is, they parenthically explain to the contemporary audience such localities that are not generally known, whether they be villages, ruins, ponds, and the like. In the Buddhist canon, this device usually refers to places where the Buddha taught. Examples include villages, otherwise completely unknown, such as Nagarvinda, and Sāla in Kosala, or Amba.sandā brāhmanagāma in Magadha, or Thullako.t.thita, and Kammāsadhamma (nigama) in Kuru land. ${ }^{56}$

Interestingly, these villages are mostly fairly close to the homeland of the Buddha; they do not occur in the rapidly Sanskritizing Videha of the former King Janaka. ${ }^{57}$

However, the the Brahmin villages quoted are concentrated in Kosala ${ }^{58}$ but they also include some in Magadha and Anga. The latter was a marginal area on the southern bend of the Ganges, while Magadha had been taboo for Brahmins for long -- even Videha was so at first, as ŚB reports. Brahmins are attested for Magadha only in very

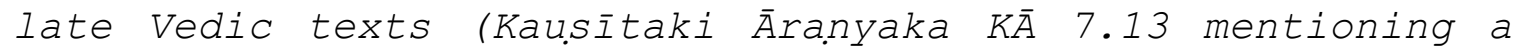
single person, Madhyama Prātibodhīputra, called magadhavāsin). ${ }^{59}$

That the Buddha actually taught in Brahmin villages of Magadha ---not just an individual Brahmin in that land-- is again indicative of the clear time difference separating the early Buddhist texts from the vedic corpus. In this sense, both the Vedic and early Păli texts may overlap, only for the early part of his life.

Again, all of this points to the transition period from the pre-urban Vedic texts and early Buddhist texts, toward the Pali text corpus, with fully blown city civilization, parks etc.

3. Political situation.

However, another point, that of the social and political development of the East has hardly been used so far in the

\footnotetext{
55 O. v. Hinüber, Hoary Past, JIABS 9, 2008: 197 sqq.

56 o. V. Hinüber Hoary Past, JIABS 9, 2008: 198 sqq.

57 In $S B, B \bar{A} U$, see $M$. Witzel, The Development of the Vedic Canon, $p$. $319 \mathrm{sqq}$.

58 o. V. Hinüber, Hoary Past, JIABS 9, 2008, 201.

59 Even in late/post-Vedic texts such as the LŚS 8.6.28 or KŚS 22.4.22, a brahmabandhu Māgadhedeśiya is mentioned as recipient of Vrātya equipment, which would mean that some Brahmins lived there by the time of the authors; cf. Macdonell-Keith, Vedic Index, 1912, VOI. II 116.
} 
current context. ${ }^{60}$ Nevertheless, there is some information about the actual political situation of the time, such as on Vedic kings, and more so in the Buddhist texts -though we must be careful, with $0 . v$. Hinüber, as »...many references to Indian history in the Tipi.taka remain doubtful...» ${ }^{61}$ Nevertheless, it will be attempted here, with Ranke, to show "wie es wirklich gewesen.» The historical information found in both sets of texts can be summed up in the following table.

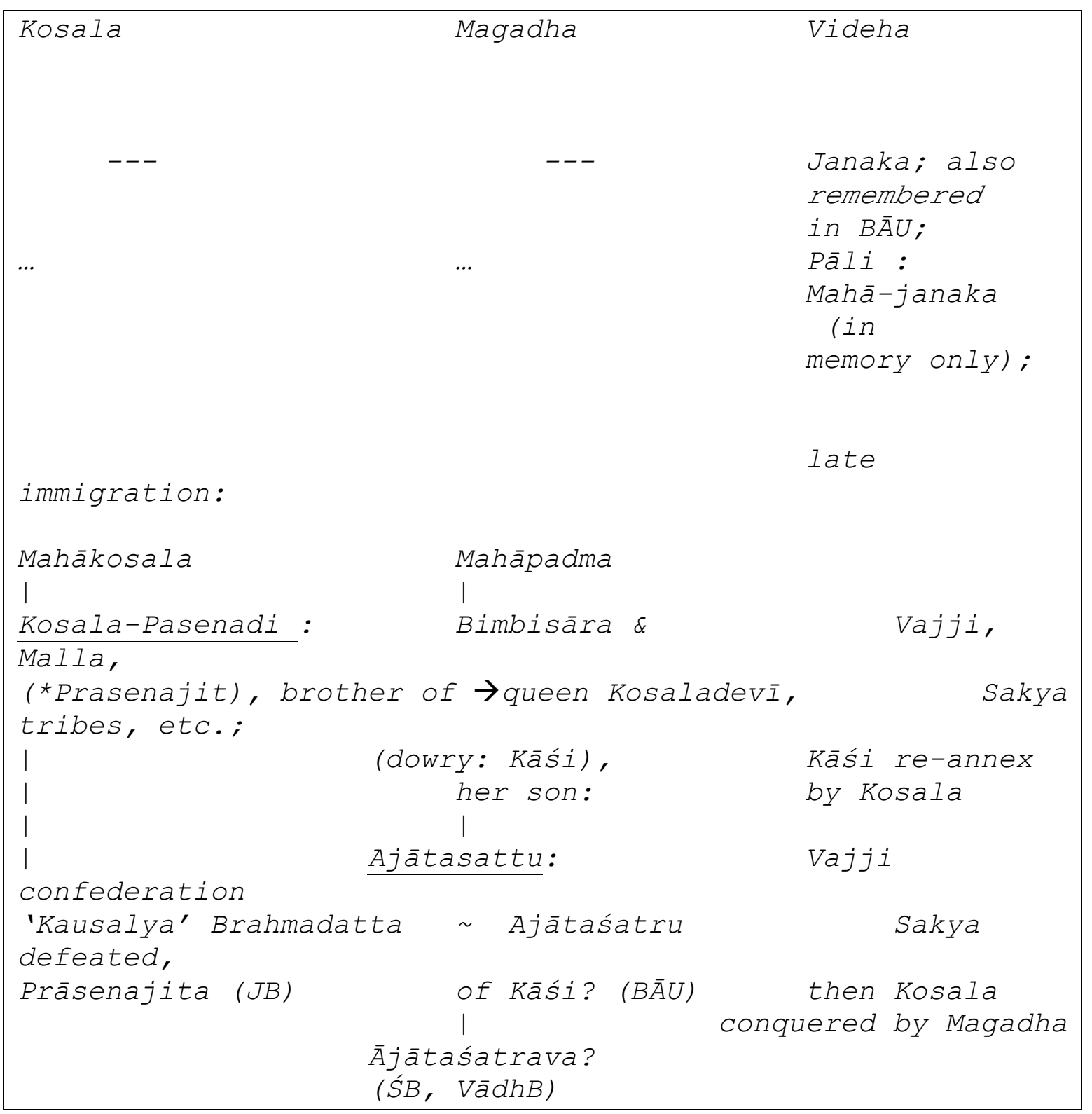

\footnotetext{
${ }^{60}$ Note the rich, if somewhat hagiographic, often undigested and noncomparative materials in G. P. Malalasekara, Dictionary of Pali proper names, and cf. T.W. Rhys-Davids, Buddhist India, London 1911, from where much historical writing of the 20 th cent. about this period has proceeded.

${ }^{61}$ Note the caveat, on historical information in the Pali texts, $0 . v$. Hinüber, Hoary Past, JIABS 9, 2008, $206 f$.
} 
The Late Vedic texts clearly indicate increasing "Sanskritization» of the eastern (OCP/BRW) territories. Both the Iksvāku Kings of Kosala (despised by western Brahmins) and those of the Videha area east of $i^{62}$ strove to emulate the successful, orthoprax Kuru model of society, religion and state. ${ }^{63}$

They imported Kuru-Pañcāla Brahmins such as Yãjnavalkya ${ }^{64}$ furthered canonization of the veda by the collection of śrauta ritual in the first incipient sutra ${ }^{65}$ and by the import of western modes of recitation of Vedic texts $^{\overline{6}}$ as opposed to the aberrant, two-tone Vedic language of the East (bhäsika, as still heard today in the Śatapatha Brāhmana), ${ }^{67}$ and by the fixation of the text of the Rgveda. ${ }^{68}$ Janaka of Videha is the prototypical king of this effort: he also organized big speech contests for Brahmins with prizes of thousands of cows and gold tied to their horns. It is to be noted, however, that Janaka was already a legendary figure (Mahājanaka) in the Pāli texts; some time clealry has passed between the accounts in the early Upanisads and those in the Păli texts, thus at a minimum, from C. $500 \mathrm{BCE}$ to $400 \mathrm{BCE}$. The same is the case even for the Brhadāranyaka Upanisad, where people compare later kings with Janaka. ${ }^{69}$

We do not know what happened to Janaka's Vedic 'reforms' during the times of the Vajji confederation, that is, during Buddha's lifetime. Apparently, the Videhas again changed their societal set-up, under pressure of the newly immigrant Vajji tribes. The Pāil canon indeed speaks of former kings of Videha (such as Mahājanaka and Nimi, ${ }^{70}$ and Janaka was remembered as a great king of the past.

\footnotetext{
62 Note the Videgha Māthava legend of the ŚB 1.4.1.10 sqq, with clear link back to the 'sacred land' of the Veda, Kuruksetra.

${ }^{63}$ For a brief summary, see M. Witzel, The Realm of the Kurus: Origins and Development of the First State in India. Nihon Minami Ajia Gakkai Zenkoku Taikai, Hokoku Yoshi, Kyoto 1989, in more detail: Early Sanskritization. Origins and development of the Kuru State. B. Kölver (ed.), Recht, Staat und Verwaltung im klassischen Indien. The state, the Law, and Administration in Classical India. München : R. Oldenbourg $1997,27-52$.

64 See M. Witzel, Yājñavalkya as ritualist and philosopher, and his personal language.

65 M. Fushimi, Baudhāyana Śrautasūtra: Development of the ritual text in Ancient India. PhD Diss., Harvard 2007.

66 Mainly, the Vājasaneyi Samhitā, see M. Witzel, The Development of the Vedic Canon, p. 324 sqq

67 M. Witzel, The Development of the Vedic Canon, p.324 sq.

68 In Śākalya's Padapātha, see M. Witzel, The Development of the Vedic Canon, p. 322 sqq.; cf. J. Bronkhorst, Greater Magadha; and: The orthoepic diaskeuasis of the Rgveda and the date of Pānini, IIJ $23,1981,83-95$.

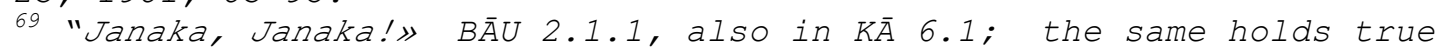
for the late Vedic Kăthaka section preserved in TB 3.10.9: Janaka has had conquered the heavenly world, where a pupil of Atyamha Äruni appears;

${ }^{70}$ Cf. G.P. Malalasekara, Dictionary of Päli proper names II 880.
} 
In sum, one has to conclude, again, that an unspecified period of time has passed between Janaka (ŚB, $B \bar{A} U$ ) and the life time of the Buddha.

Accordingly, the Vedic texts learly Upanisads, late Brāhmanas) do not yet mention the Magadha kings Bimbisāra, Ajātaśatru, and the Kosala king Prasenajit,

who are contemporaneous with the Buddh. Actually they do not mention any great kings of the East, with the exception of the (despised) Iksvāku lineage of Kosala and their favorite, King Janaka of Videha.

In contrast, the Bihar area appears quite differently in the Pāli canon. Videha was no longer a kingdom but it was, like its neighbors, including the homeland of the Buddha, an oligarchic 'republic.' Between the Late Vedic texts and the time of the Buddha, momentous developments took place in the East when a number of 'new' tribes appeared. They were not yet known to the Vedic texts, next to a few 'aboriginal' ones mentioned in the late $A B$, such as the Pulinda, Mūtíba or Andhra.

The new ones include the Sakya, Malla, Licchavi, and the Vajji themselves, who are known from Pănini as the Vrji gana (tribe) of the Panjab. The Malla, too, appear in the Jaiminìya Brāhmana as Rajasthan desert people. ${ }^{71}$ clearly a certaion section of these western gana tribes moved toward the East and settled in Bihar. Many of them, surprisingly including Videha, make out the prominent Vajji confederation of the Buddha's lifetime.

Videha clearly had, by then, reverted from a monarchical state to a tribal one, for the earlier kings of Videha are well remembered in the Păli canon, for example Janaka as a distant Mahājanaka. The change from the Vedic, Sanskritizing kingdom to a Vajjian «republic», again, is another clear indication of the time diference between both corpora. That includes the earliest texts of Buddhism as the Buddha clearly interacted with the Sakyas and Vajjis as well as with their enemies, the Kosala king Pasenadi, and the Magadha kings Bimbisāra and Ajāsattu.

All the preceding points indicate a period of social and political change around $450 \mathrm{BCE}$, and a clear time difference between the Late Vedic texts and the earliest Buddhist ones, still pre-Păli, of the lifetime of the Buddha.

\section{Herodotus' ascetics.}

\footnotetext{
71 Note that a section of the Malloi still appeared in Alexander's time in the lower Panjab: see Arrian, Anabasis 5.22.2, 6.4.1sqq, 6.4.3, 6.5.4, 6.6.1sq9, 6.14.2, Indikā 4.10, 19.8.
} 
This is also supported, exceptionally, by an outside source, Herodotus (c. 484-425 BCE). Due to the expansion of the Persian empire into Gandhāra and Sindh (after 530/519 BCE), he had some knowledge of Northwest India, acquired from contemporary Greek authors in the service of the Persian King of Kings, and from the hearsay of merchants. Writing at C. 430/425 BCE, he describes the northwestern area, as one of wild barbarian tribes that eat raw meat butt also of vegetarian ascetics. ${ }^{72}$

This relatively early date presupposes a lively culture of ascetics, wandering all over northern India, before C. $430 \mathrm{BCE}$, and this agrees with the early experiences of the Buddha at age 30 (C. $430 \mathrm{BCE}$ ), when he joined other Eastern ascetics and with uncertain Jaina traditions about Pārśva, the supposed predecessor of Mahāvìra, at C. 750 BCE.

An early, though only relative date is also indicated by the wanderings of Yājñavalkya's fellow Brahmin contemporaries up to Madra (N. Panjab, BĀU 3), and by the fate of Yājñavalkya himself. He became first attested 'sannyāsin' in Indian literature. ${ }^{73}$

However, as indicated, I leave aside the development of religious thought and philosophy, as such data are treacherous. For example, can we assume some form of early Sānkhya in RV 10.90, in the opposition and conjunction of purusa and virajj? Which idea then disappeared from sight for many centuries.

Nevertheless, the Buddha's non-ätman theory is clearly based on the long history of atman speculation in the late Brāhmanas and early Upanisads.

\section{\$ 4. The political situation}

Taking now a closer look at the political situation during the life time of the Buddha (see table 1), we can discern a triangular set up between the powerful kingdoms of Kosala and Magadha on the one hand and the eqaully powerful Vajjian confederation on the other. A few marginal states, such as the kingdoms of Kāśi (Bārānasi) and Kosāmbi/Kausāambì in the lower Doāb also played a varying role.

Kāśi was a marginal, barely Vedicized territory even in Late Vedic texts, ${ }^{74}$ and the heavily Sanskritizing Kosala was still half-despised by Vedic Brahmins. Their kings belonged to the «degenerate» Iksvāku lineage, and their

\footnotetext{
72 Herodotus, Histories 3.97.

73 If we neglect legends about predecessors of Vardhamāna Mahāvīra, such as the second last Tìrthankara, Pārśva.

${ }^{74}$ In the $S^{B}$, they are said to have lost the sacred fires for 10

generations, i.e. they never possessed them.
} 
crown sprince spoke like the easterners (with two tones?) and "could not be understood." ${ }^{75}$

According to the Pāli texts, Kāśi and Kosala were in constant conflict and conquered and reconquered each other several times. During the Buddha's lifetime, Kāśi was finally conquered by Kosala and was given to Pasenadi's sister Kosaladevi as dowry when she was married to Bimbisāra of Magadha. Her son Ajātasattu thus was also the King of Kàsi. These kings contemporary with the Buddha are best dated according to his revised life time. As is well known now, he is thought to have lived for 80 years from $c$. 460 to $380 \mathrm{BCE} \cdot{ }^{76}$

However, there are a few precious data in Late Vedic texts that, on first view, seem to indicate an overlap with the kings attested during the lifetime of the Buddha. For example, a possible descendant of Pasenadi could be the Vedic king Brahmadatta Prāsenajita of Kosala. He occurs just once in a ritual discussion, and as an isolated reference, in the midst of a Middle to Late Vedic Brāhmana text (JB I 337-8: \$115). ${ }^{77}$ Also mentioned is his Purohita, who, curiously, is called Brahmadatta as well, but whose patronym is Caikitaneya and his clan name is Dālbhya. ${ }^{78}$

The Jaiminiya Br. tale is told in perfect tense, ${ }^{79}$ which is the contemporary style of the late Brāhmanas ${ }^{80}$ of the "southeastern Koine." The passage is somewhat corrupt, so that neither Caland nor Bodewitz translated it in its entirety. ${ }^{81}$

This Kosala king (Kausalyo rājā), called Brahmadatta, had a son who "speaks like the Easterners» and could not be understood. This criticism, ${ }^{82}$ however, befits much more the low esteem for the emerging Kosala lineage than the prominent role of Kosala during the lifetime of the Buddha.

\footnotetext{
75 JB $1.337 \$ 115$.

76 See H. Bechert (ed.), Die Datierung des historischen Buddha. AAWG 189, 194, 222, Göttingen 1991, 1992, 1997. -- According to older Indological accounts, he lived from 563-483 BCE; similarly in Ceylonese dating.

77 H. Bodewitz, The Jyotistoma ritual: Jaiminìya-Brāhmana I, 66-364. Introduction, translation and commentary. Leiden 1990, transl.p. 191, comm. 314.

78 Possibly indicating the lineage of the famous Pañcāla king Keśin Dālbhya (or Dārbhya), who was responsible for the invention and subsequent insertion of the Kaisinì díksà into the Soma ritual, see VādhB 4.37: 47 sqq, swapping knowledge with a dead king as goose; cf. KB 7.4, JB 2.53.

79 M. Witzel, On the origin of the literary device of the 'Frame Story'.

80 M. Witzel, Tracing the Vedic dialects, p. 139 sqq.

81 See comments by W. Caland, Das Jaiminiya-Brāhmana in Auswahl. Amsterdam 1919: 129, and cf. H. W. Bodewitz, The Jyotis.toma ritual, transl. p. 191, comm. p. 314.

82 Cf. H. W. Bodewitz, The Jyoti.s.toma ritual: p. 314.
} 
It is thus not entirely clear whether this particular Prāsenajita could indeed the son of Pasenadi.

Prāsenajita would be a descendant of *Prasenajit, who is not attested in Vedic, and would have lived a generation later than *Prasenajit/Pasenadi of Kosala. There is indeed a late very tradition of Brahmadatta as one of the sons of Pasenadi. ${ }^{83}$

However, Brahmadatta is a very common name in the Pāli texts, where it occurs, among others, as the name of various kings of Kosala and Kăsi. ${ }^{84}$ The name was also fairly common in late Vedic ${ }^{85}$ and it is thus possible that some confusion entered both the Vedic and Pāli texts: 'Brahmadatta' is the name of several more or less famous persons. Such confusion is seen earlier with the accounts of the Rgvedic Ten Kings' Battle, ${ }^{86}$ where the Brāhmana texts confuse kings of the Rgvedic Bharata lineage and the location of the sudās battle that had occurred some centuries earlier.

Second, the Magadha king Ajātasattu Vedehiputta may appear in some late Vedic texts as Ajātaśatru, both as a king of Kāsi $i^{87}$ as well as a king of the Kurus. ${ }^{88}$ However, it is not clear whether the Vedic Ajātaśatru of Kāsi is the same king as Ajātasattu of Magadha. Their identitity is, at least, possible. According to Buddhist sources, the king of Kosala, Pasenadi, gave Kàsi to his daughter Kosaladevì as dowry when she married king Bimbisāra of Magadha. Therefore, their son Ajātaśattu became king of Kāśi as well. The Vedic texts may have mentioned him as just as such, as to avoid naming the despised Magadha, an argumentum ex nihilo.

\footnotetext{
83 Only according to the Theragāthā commentary 1.460, see G. $P$. Malalasekara, Dictionary of Pali proper names, II p. 171; 174, n. 39, the latter according to the (late) Divyāvadāna 369.

${ }^{84}$ Vin. 1.342 sqq: Brahmadatta, Purohita of the Kāsi King; Theragāthā 441-446 (221) by Brahmadatta, son of the King of Kosala, born at Sāvatthī «in this Buddha age»; and in the Jātakas, Divyāvadāna. Among these, the Vin. and Theragāthā are sufficiently old; the rest of the attestations can be due to a later or indeed, a very late tradition. 85 ŚB 14.4.1.26, JB 1.333, 337, JUB 1.59.1, 1.38.1, BĀU 1.3.24, VaikhGS 2.7, cf. Păn. 4.1.99, see M. Witzel, Tracing the Vedic dialects, n. 264.

86 For this see M. Witzel, Rgvedic history: poets, chieftains and politics. in: G.Erdosy (ed.) Language, Material Culture and Ethnicity. The Indo-Aryans of Ancient South Asia, ed. G. Erdosy, Berlin/New York: de Gruyter 1995, 307-352; and: The Vedas and the Epics: Some Comparative Notes on Persons, Lineages, Geography, and Grammar. In: P. Koskikallio (ed.) Epics, Khilas, and Puranas. Continuities and Ruptures. Proceedings of the Third Dubrovnik International Conference on the Sanskrit Epics and Puranas. September 2002. Zagreb: Croatian Academy of Sciences and the Arts 2005: 2180 .

87 BĀU 2.1.1-17, KausU 4.1-17,19.

88 VādhBr. 4.75.
} 
However, to begin with, the designation ajàtasatru "one who has 'unborn' (non-existent) enemies» is not rare and is indeed found since the Rgveda, ${ }^{89}$ It can have been the name of many men ever since. One of them, the Kuru King Ajātaśatru, is definitely to be excluded as being identical with Ajātasattu. He is the son of a Medhātithi (a maidhătitha), not of Bimbisāra or whathever this Magadha king may have been called in Vedic. ${ }^{90}$

Yet, the Veda also has one mentioning of a son of a certain Ajātraśatru, called Bhadrasena Ājātaśatrava. ${ }^{91}$ This occurs in a ritual discussion of the Sautrāmani ritual. He was bewitched by one Āruni (whose son Kusurbinda has an autochthonous name). The famous Yājñavalkya is said to have responded to this kind of sorcery. This would place the tale in pre-Magadhan times.

It is however notable that Ajātaśatru is not called a king here. The appearance of Äruni could point to the Brāhmana/Upanisad period ${ }^{92}$ but some Ārunis are also mentioned in an early Samhitā text. ${ }^{93}$

In addition, the $S B$ passage ocurs in the closing statements of the discussion of the sautrāmani, just before the daksinās (ŚB 5.5.5.16-18), and thus can have been added any time before the (late) redaction of the text. ${ }^{94}$

Based on these data, Bhadrasena can be the son of any of the Ajātaśatrus in the Veda, mentioned or not, since the $R V$, though the juxtaposition of Yājnavalkya weighs in favor of a late Vedic timeframe of the tale. ${ }^{95}$

Importantly, the late Aitareya-Brāhmana already speaks of kings not belonging to the Ksatriya class - which is typical for the Nanda and Maurya dynasties and will have been so for the earlier Magadha kings as well.

89 RV 5.34.1, 8.93.15, PS 15.2.2; ŚB 14.5.1.1 sqq, KĀ 6.1; as king of Kāśi: BĀU 2.1.1-17, KausU 4.1-17,19; ĀŚS, ŚŚS; for later

explanations in the Pāli comm., see G. P. Malalasekara, Dictionary of Pali proper names, I 34.

90 Maidhātitha, whose clan ancestor Medhātithi is known to the RV, does not occur in the Pāli canon, see G. P. Malalasakara, Dictionary of Pali Proper names.

91 ŚB 5.5.5.14 = ŚBK 7.5.3.11.

92 For Uddālaka Āruni, see Macdonell-Keith, Vedic Index I, $87 f f$.

93 KS 13.12: 194.7, where the only manuscript available then (Ch, a late Kashmirian style Nāgari paper ms.) has, however, arunayo, who are mentioned next to the Kanvas, Garbhas, Yāskas, and Kāpeyas.

94 M. Witzel, The Development of the Vedic Canon and its Schools, $p$. 314 sqq. 327 sqq.

95 ŚB 5.5.55.14: Āruni, not, with Eggeling's translation of ŚB: Ārani; Eggeling says: «Ājātaśatru of Kāśí (sic!)» was «very proficient in speculative theology, and jealous in this respect, of King Janaka of Videha.» It is unclear from where Eggeling extracted this information, as Ajātaśatru appears in the Veda only here, and along with Gārgya and Yājñavalkya in BĀU 2.1.1-17, Kau.sU 4.1-17,19, (and, unrelated as king of the Kuru)! At best, on can adduce the quote of people shouting «Janaka, Janaka!» in BĀU 2.1.1., Kau.sU 4.1.1. 
In sum, both the names Ajātaśatru and Bhadrasena were common in Late Vedic and at the time of the Buddha. As really existent historical personalities, the Vedic ones do not agree very well with the Buddha's contemporaries. At best, we may hesitatingky accept the Satapatha Brāhmana's Bhadrasena Ājataśatrava and a Kāśi king Ajātaśātru as referring to Ajātasattu, who perhaps does not appear otherwise in the Veda as to avoid the mentioning of Magadha. Though the latter is possible ${ }^{96}$ it remains an ex nihilo argument, which is always better avoided.

Indeed, Ajātraśatru of Magadha is unknown to even the latest Vedic texts, though a Brahmin living in Magadha occurs in a very late Äranyaka. Most likely, Ajātaśatru was too late to be included here. All Vedic kings mentioned are non-Magadha ones. Magadha had not yet emerged as a major player in the East.

This contrasts remarkably with the Buddha's many conversations with Pasenadi of Kosala, Bimbisāra and Ajātasattu of Magadha, notably his political discussion about the Vajji confederation with Ajātaśattu's Brahmin(!) minister Vassakāra.

However, the Vajji (V.rji), Sakya and other late immigrants into the East do not occur in Late Vedic texts (with the exception of the Malla), -- which again points to a certain gap between the late Vedic and the early Buddhist $t^{97}$ exts. The Sakya etc. do not appear as anti-Brahmanic in the early Buddhist texts: apparently some acculturation occurred after their immigration and before the testimony of the earliest Buddhist texts.

In sum, it is unavoidable to conclude, that -- in spite of some uncertain allusions to Ajātaśatru and Prasenajit and their sons-- an undefined amount of time must have passed between the Late Vedic and early Buddhist texts. These data are summed up in table 3.

TABLE 3.

$V E D A$ :

$P \bar{A} L I:$

Vedic texts, down to:

Immigration of Iksvāku, Pūru late immigrations:

Malla,Vajji, Sakya

Kosala \& Videha: acculturation

to Kuru orthopraxy

\footnotetext{
96 M. Witzel, The Development of the Vedic Canon and its Schools, $p$. 319 sq; cf. J. Bronkhorst, Greater Magadha.

97 Some Late Upanisadic additions (such as BĀU 3.9, end) not withstanding.
} 


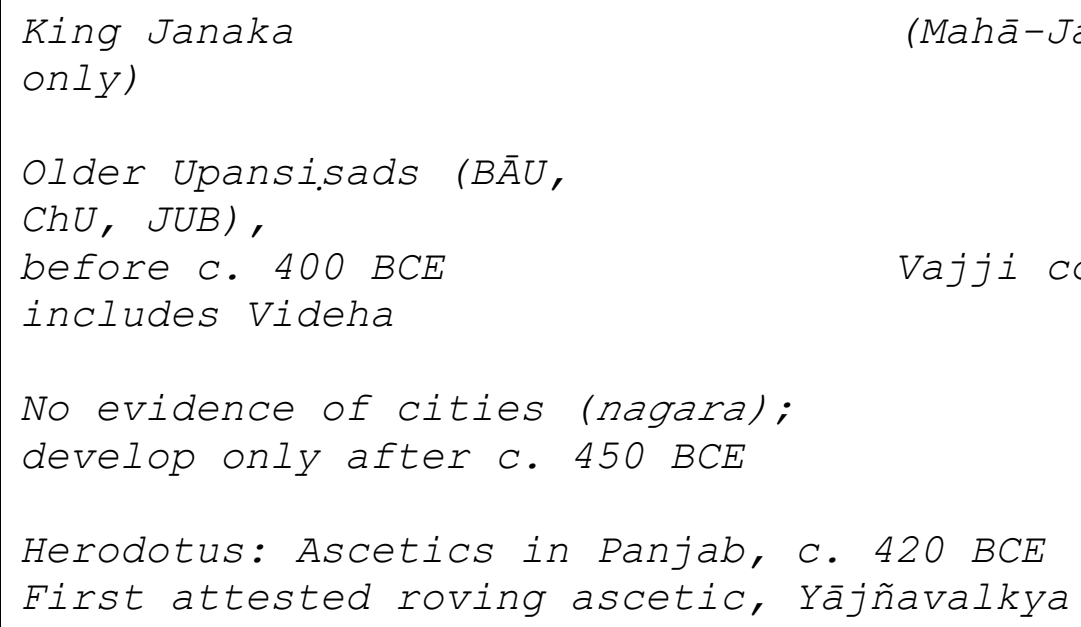




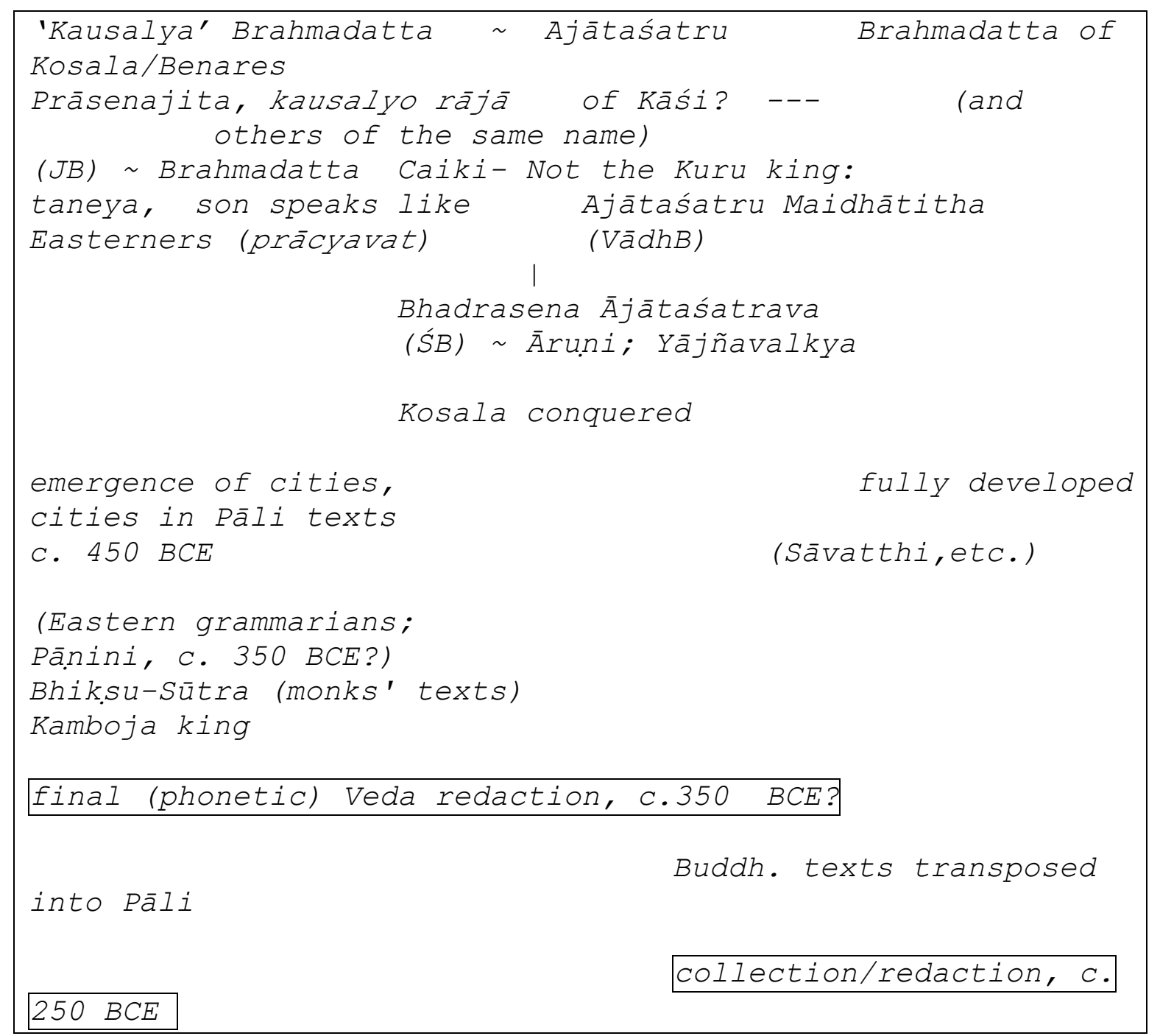

\section{\$ 5 Conclusion}

Reviewing the materials adduced so far, the following can be stated.

* The Buddha lived in time of changes from villages to cities and from tribal states to large monarchies.

* Though he still knew about the living Vedic language (chandas), his own language, an early eastern Middle Indic of the borderland between Kosala and Videha, still had the perfect, which coincides with the standard of Eastern Vedic spoken in Kosala-Videha.

* The large majority of the Vedic texts, including that of the oldest Upanisads (BĀU, JUB, ChU) preceded him, and he reacted against the Upanisadic àtman theories.

* This occurred in a period where ascetics were common from Gandhāra to Bihar, c. 430 BCE, as Herodotus attests and Jaina tradition suggests, -- when both the Buddhist/Jaina order developed. 
* The eastern countries and kings mentioned in Late Vedic texts are those well before the earliest Buddhist texts. Magadha was not yet a major power. Its prominent king Ajātasattu is not mentioned and can be identified with one of the Vedic Ajātaśatrus only with difficulty. In addition Bhadrasena, Ajātaśatru's son, belongs to a period well before that of Ajātasattu, to the time of Yajñavalkya of $B \bar{A} U$.

Cumulative evidence -- historical, archaeological and textual-- of the Late Vedic and early Buddhist texts therefore points to a clear time gap between both text corpora and the time periods they depict.

In sum, the results of this limited investigation, which intentionally excluded the development of thought, uphold the "traditional" view of several consecutive linguistic, textual and historical layers from Vedic to the earliest Buddhist texts. We can be fairly certain, that this sums up "wie es wirklich gewesen" -- evam etam bhütapubbam. ${ }^{98}$

98 Thus, in the words of the Păli canon, D. II 167,20; note $0 . \mathrm{V}$. Hinüber, Hoary Past, JIABS 9, 2008: 209. 